\title{
LINGUISTIC CHOICES BY INDONESIAN-SPEAKING ADOLESCENTS: A CASE STUDY IN TANGERANG
}

\author{
Bernadette Kushartanti ${ }^{1} \quad$ Zakiyah $^{2}$ \\ Faculty of Humanities, Universitas Indonesia ${ }^{12}$ \\ kushartanti.hum@ui.ac.id ${ }^{1}$ \\ kiki.zakiyah@gmail.com²
}

\begin{abstract}
This study presents the result of a survey on linguistic choices by adolescents who live in Tangerang, a neighboring area of Jakarta. In this study, we observed their use of Bahasa Indonesia (BI), Colloquial Jakarta Indonesian (CJI), foreign language (FL), regional language $(R L)$, and mixed language $(M L)$ in interactions with different addresees in daily activities: parents, teachers, friends, siblings, grandparents, uncles/aunts, and new acquaintances. Data in this study were collected from questionnaires, distributed at two secondary schools (SMP) and two senior high schools - a sekolah menengah umum (SMU) 'general senior high school' and a sekolah menengah kejuruan (SMK) 'vocational high school' which are located in Tangerang. The participants in this study are the students, aged 13 to 19 years old (N=748). It is found that BI and CJI were frequently used by these teenagers. They tended to use BI in interactions - spoken and written - with the older and respected people (teachers, parents, and grandparents) or those who are not familiar with them. CJI is used to those who are socially equal to them. Some of them used ML. Only a few of these participants use RL, and very few use FL. This study also finds that there are differences on the patterns between the use of BI and CJI in spoken and written interactions. Another factor that makes the difference between these varieties is the educational level. Findings in this study indicate that these varieties - especially BI and CJI - have different functions, and the respondents' choices are strongly influenced by the status of the participants and the social contexts.
\end{abstract}

Keywords: linguistic choices, youth language, adolescents, Indonesian

\begin{abstract}
Abstrak
Penelitian ini menyajikan hasil survei mengenai pilihan bahasa oleh remaja yang tinggal di Tangerang, daerah yang berbatasan dengan Jakarta. Dalam penelitian ini, kami mengamati penggunaan Bahasa Indonesia (BI), Bahasa Indonesia Jakarta (CJI), bahasa asing (FL), bahasa daerah (RL), dan bahasa campuran (ML) dalam interaksi antara remaja dengan mitra tutur yang berbeda dalam kegiatan sehari-hari, yaitu dengan orang tua, guru, teman, saudara sekandung, kakek/nenek, paman/bibi, dan orang yang baru dikenal. Data penelitian ini diperoleh dari kuesioner, yang disebarkan di dua SMP, sebuah SMU, dan sebuah SMK yang berlokasi di Tangerang. Responden penelitian ini adalah para siswa di sekolah-sekolah tersebut, berusia 13-19 tahun $(\mathrm{N}=748)$. Dalam penelitian ini ditemukan bahwa BI dan CJI merupakan bahasa yang paling sering digunakan oleh para remaja. Mereka cenderung menggunakan BI - baik dalam percakapan maupun tulisan - kepada orang yang lebih tua dan orang yang dihormati (guru, orang tua, kakek/nenek), atau mereka yang belum dikenal baik. CJI digunakan untuk mereka yang secara sosial sejajar dengan kedudukan sosial remaja ini. Beberapa dari mereka menggunakan ML. Hanya sedikit dari mereka yang
\end{abstract}


menggunakan RL, dan sangat sedikit yang menggunakan FL. Penelitian ini juga menemukan perbedaan pola penggunaan BI dan CJI dalam interaksi percakapan dan tulisan. Faktor lain yang menyebabkan perbedaan penggunaan kedua variasi tersebut adalah tingkat pendidikan. Temuan dalam penelitian ini mengindikasikan bahwa bahasa-bahasa tersebut - terutama BI dan CJI - masing-masing mempunyai fungsi, dan pilihan responden sangat dipengaruhi oleh status partisipan dan konteks sosial.

Kata-kata kunci: pilihan bahasa, bahasa remaja, remaja, bahasa Indonesia

\section{INTRODUCTION}

In multilingual communities, there are several influencing factors that can make someone choose a certain style, variety, or language. Holmes $(2013$, p. 9) proposed four main factors in language choices: participants, setting or social context of interaction, topic, and function. In interactions, there are two parties that have to be considered: the one who is speaking and to whom they are speaking. Bell (1984, 1991) proposed a sociolinguistic model in which the audience plays an important role for the speaker in interaction, namely audience design. In this model, the speaker designs their style (or language) for their audience. According to Bell (2001, p. 146), "Speakers have a fine-grained ability to design their style for a range of different addressees, as well as for other audience members". In addition, Holmes (2013) suggested that there are social dimensions related to the aforementioned factors: social distance and status that concerned with participants relationships, formality which is related to the setting or type of interaction, and functional scales related to the purposes or topic of conversation (Holmes, 2013, pp. 9-11). These factors and dimensions are applicable in Indonesia, which is known as a multilingual and multicultural country.

For Indonesian younger generations who live in big cities - especially those who were born around the $2000 \mathrm{~s}$ - using various styles, varieties, and languages in daily activities is not uncommon. In Jakarta and its surroundings (Bogor, Depok, Tangerang, Bekasi), generally middle class families prefer to speak with their children in Indonesian rather than in their vernacular or regional languages. Therefore, Indonesian, in general, becomes the first language of the children (see also Wouk 1999; Sarwono 2014). However, a regional language is sometimes used among members of some ethnic communities (see Na'im and Syaputra 2011), and that makes it possible for children to learn the regional language.

Today, many families also introduce their children to a foreign language or foreign languages at a very young age. The linguistic repertoire of these younger generation of Indonesian expands as they reach school years. Generally, they formally learn Bahasa Indonesia, the standard Indonesian, as the medium of instruction at school, while they still use colloquial Indonesian in less formal situations. They also learn English, the main foreign language taught in Indonesian schools. The national curriculum includes a regional language as a subject taught at some schools, which sometimes considered as a "foreign language" for those who come from different ethnic groups. The fluency of the languages other than Indonesian - foreign and regional - depends on how they use it in their daily activities.

We can say that these younger generations of Indonesian are considered as multilinguals, given that they have various linguistic inputs: standard and colloquial varieties of Indonesian, regional language, and foreign language. As they grow, especially when they reach adolescence and become socially active, they create their own "language". The use of novel varieties, including styles, registers, dialects, or multiple languages, is common in linguistic practices of youth language. This is a part of 
constructing their identity (Eckert, 2000; Bucholtz, 2001), and in that way they align with their peers (Bucholtz, 2006). At least, Indonesian, a regional language, and (a) foreign language(s) are put into language practices of adolescents in their daily activities (Tamtomo, 2016; Djenar et al., 2018). As a consequence, they may mix these languages when they are talking at home or at school, or with their peer group or other communities.

In the studies of today's Indonesian youth, identity, language, and social media become the core topics. The Jakartan youth are considered as the trend-setters. Sarwono (2014, p. 53) pointed out that the younger generation born in or having migrated to Jakarta hardly speaks their native language or the language spoken by the elders. She also indicated that culture is strongly influenced by media. Thus, the attention on the study of Indonesian youth language today does not only go to spoken interactions.

Development in globalization, science, and technology has an important influence in youth language. Besides, as they grow, the need to expand their social circle and to be connected with the outer world becomes one of the foci in adolescence. Peer group becomes an important influence (see also Papalia and Martorell, 2015). Therefore, social media such as Facebook, Twitter, Instagram, Line, Whatsapp become the media of expression in the written form, and Indonesian adolescents are among the most avid users (Djenar, 2014, p. 166). Studies on Indonesian youth language in recents years especially in written forms - found some tendencies in "violation" of the standard Indonesian (e.g. Subyatningsih, 2007, 2016). The negative viewpoint of youth language sees it as carelessness and less developed writing skills (Djenar, 2015). However, Djenar (2012, p. 35) said that "[...] view of literature which holds that the function of adolescent fiction is to educate readers on the aesthetic function of language and sound moral values $[\ldots]$ is an articulation of a desire to safeguard the existence of a linguistic authority". Besides, what is considered as "violation" is actually a part of identity construction for adolescents (Eckert, 2000; Bucholtz, 2001).

Studies on Indonesian youth languages were conducted with various foci in both forms: written (e.g. Subyatningsih, 2007; Djenar, 2008; Tamtomo, 2015; Djenar ,2015; Djenar \& Ewing, 2015; Ewing, 2015; Subyatningsih, 2016; Indrayanti, 2017; Swandy, 2017) and spoken (e.g. Yannuar \& Kadarisman, 2013; Djenar \& Ewing, 2015; Manns, 2015). It is important to have a closer look on the users, especially on the linguistic preferences amid their linguistic repertoire.

This study presents the results of a survey on linguistic choices by Indonesian-speaking adolescents in interaction with different addressees. Particularly, we observed the adolescents who speak the Jakarta Indonesian and live in Jakarta and its surroundings. Our focus is on how they used the Indonesian varieties (Bahasa Indonesia, hereinafter BI; and Colloquial Jakarta Indonesian, or CJI), regional language, foreign language(s), and the mixture of these language. We also examined the influence of the addressees of spoken and written interactions in the language choices. ${ }^{i}$

In the present study, our respondents are adolescents who live in Tangerang, Banten - a neighboring area of Jakarta. They are students of secondary school (or Sekolah Menengah Pertama, SMP) - both state and private, a state senior high school (Sekolah Menengah Umum, SMU), and a private vocational high school (Sekolah Menengah Kejuruan, SMK) in the same area. Findings from a research by Lembaga Demografi Fakultas Ekonomi dan Bisnis Universitas Indonesia (a universitybased demographic institution) show that Tangerang is the choice of Jakarta residents who find it difficult to get a comfortable place to live (Sitanala, 2005). Based on a study conducted by Ananta et al. (2015), Banten, the province where Tangerang is located, has a population of 9,123,281 people, and $95.21 \%$ of them are able to speak Bahasa Indonesia. As an area located in the border of Jakarta and West Java, Tangerang was originally dominated by Chinese and Betawi ethnic groups. However, fastdeveloping infrastructures connecting to Jakarta and the commuting new inhabitants (who live in Tangerang and work in Jakarta; see Forbes, 2004) have an impact on access to communication to be unlimited, which indirectly results in the use of the same language(s) as in Jakarta. 


\section{METHOD}

This survey used questionnaires as the main data instrument. Before the survey, we observed the language use at these schools. We found that the students in general used CJI in their interactions with friends. The interactions between students and teachers in the classroom, as we overheard, used both BI and CJI. We also heard that they sometimes used mixed languages. They also used both CJI and mixed languages with their teachers outside the classroom. Before we conducted the survey, we also conducted a pilot study with some participants (at a different school) who did not participate in the real survey. The questionnaires prepared for this study were distributed upon the schools' permission and respondents' consent.

The current study is part of a survey study on youth language use and attitudes. The questionnaires are comprised of three sections. The first section consists of questions concerning personal information of the respondent (age, gender, parents' ethnicity and occupation, first language, and whether they use regional and foreign language). We included questions on social media which are used by the respondents. The second section is on language use in which we observed BI (in the questionnaire we refer to it as Bahasa Indonesia Baku, or Standard Indonesian), CJI (in the questionnaire we refer to it as Bahasa Indonesia Jakarta, or Jakartan Indonesian), RL (in the questionnaire we refer to it as bahasa daerah 'regional language'), and FL (in the questionnaire we refer to it as bahasa asing 'foreign language'). The four observed languages, therefore, are the dependent variables. In addition, we also examined the possibility of the use of mixed languages, due to the participants' linguistic repertoire. Therefore, another dependent variable was added, namely Mixed Language (ML; in the questionnaire we refer to it as bahasa campuran 'mixed languages').

The second section consists of three subsections, namely information on the language used in verbal interactions - when they are talking and showing anger - with others (the independent variables), on the language used in social media - in which we also include participant factor, and on the language used to discuss certain topics. The independent variables, or the participant factor, that we observed are friends, parents, teacher, siblings, grandparents, uncles/aunts, and new acquaintances. The last part of the questionnaire contained fifteen questions concerning attitudes towards the aforementioned languages.

In our pilot study, it is found that the respondents (from a different school, and therefore they were not included in this study) showed their confusion on the concept of Bahasa Indonesia Jakarta, and mixed it up with Bahasa Betawi, the local language of Jakarta. Therefore, at the beginning of the survey we informed the participants about the concepts we used, including the linguistic variables and some examples to help the respondents' better understanding.

This study actually involved 751 respondents. However, we found that three questionnaires were not filled out completely. Therefore, they were excluded, and we had 748 completely filled out questionnaires to be analyzed. In this current article, we only present the respondents' sociodemographic profile and the results of quantitative analyses on language use. These results are presented in the following section. The number of respondents, based on educational level and gender, is presented in Table 1.

Table 1. Respondents Based on Educational Level and Gender

\begin{tabular}{ccccc}
\hline & Boys & Girls & NA & Total \\
\hline SMP & 150 & 210 & 18 & 378 \\
SMU & 133 & 215 & 22 & 370 \\
\hline & 283 & 425 & 40 & 748 \\
\hline
\end{tabular}

$S M P=$ Sekolah Menengah Pertama 'secondary school'; Sekolah Menengah Umum 'high school' (in this study, SMK 'Sekolah Menengah Kejuruan' is excluded) 
The age range of the SMP group was 13-16 years old and the SMU group was 14-19 years old. Of the 748 respondents, 65\% (486) were born in Tangerang, 18\% (135) in Jakarta, Bekasi, or Depok, while $17 \%$ were born outside Indonesia or Java Island. Fathers of the respondents come from various ethnic groups, but many of them are Javanese (37.6\%), Sundanese (17.9\%), Betawi (11.5\%), Minangkabau (4.5\%), Batak (6.1\%), while the others come from other ethnic groups (Chinese, Manadonese, Acehnese, Palembang, Malay, etc.). Meanwhile, many of the mothers are Javanese (38.1\%), Sundanese (21.0\%), Betawi (10.4\%), Minangkabau (3.1\%), Batak (6.4\%), while the others come from other ethnic backgrounds. Many of the fathers work as employers (37.6\%), entrepreneurs (29.7\%), civil servants (13.1\%), lecturers/teachers (2.5\%). Most of the mothers are housewives $(63.9 \%)$, some work as employers $(10.4 \%)$, civil servants $(8.3 \%)$, entrepreneurs $(7.6 \%)$, and lecturers/teachers (4.4\%). From the information about the parents' occupation, we can infer that generally, our respondents come from middle-class families. ${ }^{\text {ii }}$

We found that the respondents' first language was mostly Indonesian (86,6\%). Some of them acquired a regional language $(2.8 \%)$ and a foreign language $(0.4 \%)$ as their first language. We also found that some of the respondents were bilingual-first language acquirers; $0.8 \%$ of them acquired Indonesian-regional language, and $0.8 \%$ acquired Indonesian-foreign language. In the section on first language, $8.6 \%$ or 64 respondents did not give an answer to this question.

We found that many of the respondents did not speak a regional language and foreign language(s); but some claimed to use them. Of the 748 respondents, $40 \%$ claimed that the regional language was not used in daily activities. This finding is in line with Na'im and Syaputra (2011). We found that 21.1\% claimed that they could speak Javanese, 13.5\% Sundanese, 4.3\% Batak, 1.3\% Palembang, 5.6\% other regional languages (Betawi, Minangkabau, Manadonese, etc.), while 6.1\% claimed that they could speak more than one vernacular. Meanwhile, $31 \%$ of the respondents indicated that they did not use any foreign language. Of the 748 respondents, $58 \%$ could speak English, $9.2 \%$ claimed that they could speak more than one foreign language, $0.5 \%$ could speak Japanese, $0.4 \%$ Mandarin, and $0.3 \%$ Korean.

From the questionnaires, we also found that almost all of the respondents $(97.2 \%)$ have social media accounts. Some of them (29\%) have more than one account. There are $44.4 \%$ of the respondents who have Instagram only, $10 \%$ Whatsapp only, $2.4 \%$ twitter only, and $1.9 \%$ youtube only. We can say that the need to be connected with others is indeed clear in the respondents' responses.

\section{RESULTS AND DISCUSSION}

\section{The language choices in spoken interactions}

This section presents the results of the quantitative analysis that shows the tendencies of the respondents' language choices in spoken interactions with others. To have an illustration about individual tendencies on the use of the observed languages, we conducted a descriptive statistical analysis on the ratio of individual use of each variable. There are 12 observed conditions (talking with not-so-close friend, close friend, teacher, parents, siblings, grandparents, uncle/aunt, new aquaintances, and showing anger to a friend, an older person, a younger person, and to self) in which the observed variables were used. The results are summarized and shown in Table 2, which presents the means scores and standard deviation $(\mathrm{M}=$ mean; $\mathrm{SD}=$ standard deviation $)$. 
Table 2. The Use of BI, CJI, RL, FL, and ML in Spoken Interactions (in means scores of individual ratio and standard deviations)

\begin{tabular}{cccccc}
\hline $\mathrm{N}=748$ & $\mathrm{BI}$ & $\mathrm{CJI}$ & $\mathrm{RL}$ & $\mathrm{FL}$ & $\mathrm{ML}$ \\
\hline $\mathrm{M}$ & 0.3 & 0.5 & 0.0 & 0.0 & 0.1 \\
$\mathrm{SD}$ & 0.2 & 0.2 & 0.1 & 0.0 & 0.2 \\
\hline
\end{tabular}

Table 2 shows that the respondents tended to use $\mathrm{BI}$ and $\mathrm{CJI}$ when they interacted with others. It is indicated that they tended to choose CJI $(\mathrm{M}=0.5 ; \mathrm{SD}=0.2)$ more frequently than $\mathrm{BI}(\mathrm{M}=0.4$; $\mathrm{SD}=0.215$ ). The finding is in line with our observation on the language use at school: these students were more exposed in CJI in many activities at school. Only a few claimed that they used ML ( $M=0.1$; $\mathrm{SD}=0.2$ ), but it might be that their focus is on the use of $\mathrm{BI}$ and $\mathrm{CJI}$, the language that they use at school more frequently. We found that some - yet very few - still used RL ( $M=0.028 ; \mathrm{SD}=0.075)$, which is aligned with information on the demographic data, in that only a few respondents used RL. The use of FL is also very few $(\mathrm{M}=0.008 ; \mathrm{SD}=0.037)$. This finding is also in line with our observation. In addition, the main medium of instruction at the schools where we conducted the survey is Indonesian (both BI and CJI). Therefore, it is understandable that the use of FL is very limited.

We also observed whether there were differences between the two groups whose distinction is based on the educational level. The summary is presented in Table 3.

Table 3. The Use of BI, CJI, RL, FL, and ML in Spoken Interaction (in means scores of ratio and standard deviations) Split up by Educational Level

\begin{tabular}{ccccccc}
\hline & & BI & CJI & RL & FL & ML \\
\hline $\begin{array}{c}\text { SMP } \\
(\mathrm{N}=\end{array}$ & M & 0.4 & 0.4 & 0.0 & 0.0 & 0.1 \\
$378)$ & SD & 0.2 & 0.2 & 0.1 & 0.0 & 0.1 \\
\hline SMU & M & 0.3 & 0.5 & 0.0 & 0.0 & 0.1 \\
$(\mathrm{~N}=370)$ & SD & 0.2 & 0.3 & 0.1 & 0.0 & 0.2 \\
\hline
\end{tabular}

$\mathrm{SMP}=$ secondary school students; SMU=high school students (including SMK)

From Table 3, it is shown that there are some differences between the two groups in terms of using the language choices. From independent sample $t$-test $t^{\mathrm{iii}}$ to all of the observed variables, we found that there were significant differences in the use of BI,CJI, and ML. Students from secondary school, $\mathrm{SMP}(\mathrm{M}=0.4 ; \mathrm{SD}=0.2)$, tended to use $\mathrm{BI}$ more frequently than the older group, $\mathrm{SMU}(\mathrm{M}=0.3 ; \mathrm{SD}=0.2)$, $\mathrm{t}(746)=5.62, p=0.000$. It can be inferred that students from the younger group are more "formal" than the older students. On the other hand, findings from the analysis of CJI and ML showed the opposite. The younger group, $\mathrm{SMP}(\mathrm{M}=0.4 ; \mathrm{SD}=0.2)$ tended to use less CJI than the older one, the SMU $(\mathrm{M}=0.5$; $\mathrm{SD}=0.3), \mathrm{t}(746)=-3.59, p=0.002$, as well as on the use of ML, where there was a significant difference between the SMP $(\mathrm{M}=0.1 ; \mathrm{SD}=0.1)$ and the $\mathrm{SMU}(\mathrm{M}=0.1 ; \mathrm{SD}=0.2), \mathrm{t}(746)=-3.18, p=0.002$. Findings on the use of BI and CJI is in line with Kushartanti $(2014,2016)$, that the older the respondents are, the less BI they use. In other words, the younger group was more "formal" in their interaction with those who were regarded as respected persons, while students from the older group developed a sense of solidarity as they grew older.

Further analysis is on the language choices when they talked to others. The results are summarized and presented in Table 4, presenting the percentage of users. Table 4 indicates that the 
respondents tended to use BI when they talked with an older person or a person who was regarded as a new acquaintance. The numbers showed the following: teachers $(83.4 \%)$, new acquaintances $(56.4 \%)$, grandparents $(55.6 \%)$, uncles/aunts $(54.3 \%)$, and parents $(52.9 \%)$. The findings indicated that BI tended to be used in speaking with the people they respected, or those who were socially 'distant'. It is also found that CJI was predominantly used by the respondents when they talked to those who had equal positions or peer group: not-so-close friends (68\%), close friends $(67.4 \%)$, and siblings $(60.6 \%)$. In other words, CJI tended to be used in speaking with people who were 'equal' or socially 'closer'. Table 4 also demonstrates that some of respondents still used RL - even though are not many, and the use increased as they talked to grandparents (12.4\%). The use of ML increased when they talked to close friends $(27.5 \%)$, but the number who used it when they spoke to other participants was also limited. It is also found that only a few of the respondents in this study used FL to the observed participants. An explanation on the finding is apparently related to the foreign language skills. However, this should be explored with different methods.

Table 4. The Language Choices (by Users) to Talk with Different Addressees

\begin{tabular}{lccccc}
\hline \multirow{2}{*}{$\mathrm{N}=748$} & $\mathbf{B I}$ & $\mathbf{C J I}$ & $\mathbf{R L}$ & $\mathbf{F L}$ & $\mathbf{M L}$ \\
\cline { 2 - 6 } & $\mathbf{( \% )}$ & $\mathbf{( \% )}$ & $\mathbf{( \% )}$ & $\mathbf{( \% )}$ & $\mathbf{( \% )}$ \\
\hline Close Friend & 3.9 & 67.4 & 0.5 & 0.5 & 27.5 \\
Not-so-close Friend & 25.8 & 68 & 0.4 & 0.4 & 4.4 \\
Teachers & 83.4 & 14.6 & 0.3 & 0.1 & 1.1 \\
Parent & 52.9 & 29.5 & 5.3 & 0.1 & 11.8 \\
Siblings & 17.6 & 60.6 & 2.9 & 0.8 & 17.1 \\
Grandparents & 55.6 & 24.1 & 12.4 & 0.3 & 6.8 \\
Uncle/Aunts & 54.3 & 29.9 & 7.2 & 0 & 7.8 \\
New Acquaintances & 56.4 & 39.6 & 0.3 & 0.3 & 2.1 \\
\hline
\end{tabular}

The findings presented in Table 4 show that the respondents did design their language or style when they were interacting with certain addressees. The language choices also indicated the function in social contexts as well: BI was used to an addressee who was considered as having "high" status, and therefore they also showed distance and low solidarity. CJI was used to an addresse who was considered as having an equal status, and therefore they also showed high solidarity. The infrequent use of RL and FL in this study is in line with personal information we obtained from the questionnaires. As it was described previously, the regional language was not used by $40 \%$ of the respondents in daily activities; $31 \%$ respondents did not use any foreign language. Meanwhile, it is shown that the respondents tended not to claim that they used ML. The result from the descriptive statistical analysis is not align with our observation before we conducted the survey, nor with Tamtomo's (2016) and Djenar et al.'s (2018) findings. A tentative explanation on this finding may deal with the respondents' focus on the two Indonesian varieties.

\section{The language choices in written interactions}

This section presents the results of quantitative analysis that shows the tendencies of the respondents' language choices in written interactions with others. To have an illustration about individual tendencies on the use of the observed language in written forms, we conducted a descriptive statistical analysis on the ratio of individual use of each variable. There are five observed conditions (texting to friends, texting to teachers, texting to parents, ordering something online, and giving comments on posts in social 
media) in which the observed variables were used. The results are summarized and shown in Table 5, which presents the means scores and standard deviation.

Table 5. The Use of BI, CJI, RL, FL, and ML in Written Interactions (in means scores of individual ratio and standard deviations)

\begin{tabular}{cccccc}
\hline & BI & CJI & RL & FL & ML \\
\hline M & 0.5 & 0.4 & 0.0 & 0.0 & 0.1 \\
SD & 0.2 & 0.2 & 0.1 & 0.1 & 0.2 \\
\hline
\end{tabular}

As in spoken interactions, the use of BI and CJI was dominant in written interactions. Yet, the distribution patterns of $\mathrm{BI}$ and CJI shows discrepancy: the respondents tended to use $\mathrm{BI}(\mathrm{M}=0.5$; $\mathrm{SD}=0.2)$ more frequently than $\mathrm{CJI}(\mathrm{M}=0.4 ; \mathrm{SD}=0.2)$. The distribution patterns of $\mathrm{ML}(\mathrm{M}=0.1 ; \mathrm{SD}=0.2)$ in written forms, nevertheless, are similar as in the spoken forms. As with spoken interactions, RL and FL are rarely used in written forms. A discussion of the differences between the language choices in spoken and written interactions will be presented in the next subsection.

We also observed whether there were differences between the two groups whose distinction is based on educational levels of the participants. The summary is presented in Table 6 .

Table 6. The Use of BI, CJI, RL, FL, and ML in Written Interaction (in means scores of ratio and standard deviations) Split up by Educational Level

\begin{tabular}{ccccccc}
\hline & & BI & CJI & RL & FL & ML \\
\hline SMP & M & 0.5 & 0.3 & 0.0 & 0.0 & 0.1 \\
$(\mathrm{~N}=378)$ & SD & 0.2 & 0.2 & 0.0 & 0.0 & 0.2 \\
\hline SMU & M & 0.4 & 0.4 & 0.0 & 0.0 & 0.1 \\
$(\mathrm{~N}=370)$ & SD & 0.2 & 0.3 & 0.0 & 0.1 & 0.2 \\
\hline
\end{tabular}

Table 6 shows the same patterns of BI, CJI, and ML in terms of educational levels (see Table 3). From Table 6, it is shown that there are some tendencies and differences between the two groups in terms of using the language choices. From independent sample t-test to all of the observed variables, we found that there were significant differences in the use of BI, CJI, and ML. Students from secondary school, SMP ( $\mathrm{M}=0.5 ; \mathrm{SD}=0.2)$, tended to use $\mathrm{BI}$ more frequently than the older group, $\mathrm{SMU}(\mathrm{M}=0.4$; $\mathrm{SD}=0.2), \mathrm{t}(746)=6.20, p=0.000$. It can be inferred that besides the younger group was apparently more 'formal' than the older ones, the social context also influenced the language choices.

Findings from the analysis of CJI and ML, as in the spoken forms, show the opposite. The younger group, SMP $(M=0.3 ; \mathrm{SD}=0.2)$ tended to use less CJI than the older one, the SMU $(M=0.4$; $\mathrm{SD}=0.3), \mathrm{t}(746)=-3.82, p=0.000$, as well as on the use of ML, where there is a significant difference between the SMP $(\mathrm{M}=0.1 ; \mathrm{SD}=0.2)$ and the SMU $(\mathrm{M}=0.1 ; \mathrm{SD}=0.2), \mathrm{t}(746)=-3.95, p=0.000$. The findings suggest that besides the participants, social context may play an important role in language choices.

A further analysis was conducted to examine the language choices in texting to friends, teacher, parents, ordering (buying) something online, and giving comments in social media. The results are summarized and presented in Table 7. 
Table 7. The Language Choices (by Users) in Social Media

\begin{tabular}{llllll}
\hline \multirow{2}{*}{$\mathrm{N}=748$} & $\mathrm{BI}$ & $\mathrm{CJI}$ & $\mathrm{RL}$ & $\mathrm{FL}$ & $\mathrm{ML}$ \\
\cline { 2 - 6 } & $\mathbf{( \% )}$ & $(\%)$ & $\mathbf{( \% )}$ & $(\%)$ & $(\%)$ \\
\hline Texting to friends & 4.0 & 63.8 & 0.5 & 1.3 & 29.7 \\
Texting to teacher & 83.2 & 10.2 & 0.0 & 0.0 & 1.5 \\
Texting to parents & 58.8 & 30.3 & 2.1 & 0.1 & 5.7 \\
Ordering online & 70.5 & 23.7 & 0.4 & 0.1 & 3.7 \\
Giving comments on posts in & 18.2 & 46.4 & 0.5 & 2.1 & 19.1 \\
social media & & & & & \\
\hline
\end{tabular}

Table 7 shows that the language choices that were used in social media - or written interaction are in line with the language choices in spoken interactions. BI was used by many respondents when they were texting to their teachers $(83.2 \%)$ and texting with their parents $(58.8 \%)$ in social media. It is also found that when they were placing an online order, they tended to use BI $(70.5 \%)$. This finding is also in line with the previous analysis: they tended to use BI to those who are respected or not known well. Meanwhile, CJI dominated the language use of respondents in texting with friends $(63.8 \%)$. Moreover, in giving comments on post in social media, they tended to use CJI (46.4\%), as they interacted - assumingly - with those who were familiar with them, or their peer. The finding on the use of CJI is in line with Indrayanti (2017) and Swandy (2017), that Indonesian-speaking adolescents tended to use colloquial Indonesian in social media conversations. Table 7 also depicts that ML was not chosen by many in social media. However, it is indicated some (29.7\%) used ML in communicating with friends in social media. Meanwhile, very few chose RL and FL to interact in social media. It can be inferred from Table 7 that social media as a setting or social context was influential in the selection of respondents' language use.

\section{Language choices: A comparison between spoken and written forms}

The previous analyses indicate that the language choices by our respondents were influenced not only by the participants involved, but also the mode of interactions. This section presents a discussion on comparison between language choices in spoken and written interactions. The comparison between the modes of interaction is presented in Table 8, which presents the means scores (based on individual ratios) and standard deviation.

Table 8. BI, CJI, RL, FL, and ML in Comparison between Spoken and Written Interaction (in means scores of ratio and standard deviations)

\begin{tabular}{ccccccccccc}
\hline & \multicolumn{2}{c}{ BI } & \multicolumn{2}{c}{ CJI } & \multicolumn{2}{c}{ RL } & \multicolumn{2}{c}{ FL } & \multicolumn{2}{c}{ ML } \\
& Spoken & Written & Spoken & Written & Spoken & Written & Spoken & Written & Spoken & Written \\
\hline M & 0.4 & 0.5 & 0.5 & 0.3 & 0.0 & 0.0 & 0.0 & 0.0 & 0.1 & 0.1 \\
SD & 0.3 & 0.2 & 0.2 & 0.2 & 0.1 & 0.0 & 0.0 & 0.0 & 0.2 & 0.2 \\
\hline
\end{tabular}

Table 8 demonstrates the differences between spoken and written interactions, especially on the use of BI, CJI, and RL. It is shown that the mean score of $\mathrm{BI}$ is higher in written interaction $(\mathrm{M}=0.5$; $\mathrm{SD}=0.2)$ than in spoken interaction $(\mathrm{M}=0.4 ; \mathrm{SD}=0.3)$. The difference between spoken and written is significant $(p=0.000)$. On the contrary, the mean score of CJI is higher in spoken interaction $(\mathrm{M}=0.5$; $\mathrm{SD}=0.2)$ than in written interaction $(\mathrm{M}=0.3 ; \mathrm{SD}=0.2)$. The difference between spoken and written is also significant $(p=0.000)$. These findings suggest that both $\mathrm{BI}$ and CJI have their own respective functions. It is also suggested that, for the respondents, CJI was more likely more convenient to use in 
face-to-face interactions. This also applies in the use of RL which was more preferable for spoken interaction ( $\mathrm{M}=0.028 ; \mathrm{SD}=0.075)$ than written $(\mathrm{M}=0,07 ; \mathrm{SD}=0,047)$. Note that this is the language used to the elders. The difference between spoken and written is also significant $(p=0.000)$. As Milroy and Milroy (2012, p. 54) suggested, "[...] speech activity can rely on a number of situational factors to help convey meaning $[\ldots]$ ]". The situational factors can be supported by tone of voice, intonation, emphasis, or gestural and facial expressions. Meanwhile, it is suggested that BI was more preferable for written interactions, as writing is a more 'careful' and planned activity. We also found that for the respondents, ML could be used in both spoken and written interactions, but it was limited for friends or those whose social status were equal. Findings on BI, CJI, RL, and ML showed that besides the social status of the audience that influenced the linguistic choices, the social context was influential as well.

\section{CONCLUDING REMARKS AND FUTURE PERSPECTIVES}

This study examines the language choices by Indonesian-speaking adolescents in Tangerang. The observed languages are Bahasa Indonesia (BI), Colloquial Jakarta Indonesian (CJI), regional language $(\mathrm{RL})$, and foreign language (FL). We also examined the use of mixed language (ML). From the quantitative analysis, it is found that $\mathrm{BI}$ and $\mathrm{CJI}$ were dominantly used by the respondents to interact with the addressees. BI was used to talk or text older, respected person, or new acquaintances. Meanwhile, CJI, as well as ML, tended to be used to those who are socially equal with them. However, it is also shown that the users of ML are limited. The use of RL was increasing when the respondents talked to grandparents. Only a few used FL. This study confirmed that participants and social contexts are factors that have important role in language choices by Indonesian-speaking adolescents in Tangerang. It is also found that, albeit the language use were varied, the use of local, foreign, and mixed language did not seem to shift the use of Indonesian - both the standard and colloquial.

Several notes should be put forward for consideration. Firstly, Indonesian is the first language that influences language selection. This finding is related to the research method (a survey with questionnaire as the main instrument) and the place where the research was conducted (school). It is possible that respondents answered "what might be a good answer". Second, there is a tendency that the use of CJI was more dominant in the older group. The significant difference suggests a direction of language change, although more data (from other areas) is still needed to support this argument. Third, this study corroborates the fact that the use of regional languages is decreasing as they are only used when the respondents interact with the elders, while the mixed language will apparently be more frequent in use. Fourth, as today the use of foreign languages is almost everywhere, finding that foreign language was the least choices in this study is rather surprising. All these findings should be confirmed with supporting methods and data, in order to have a comprehensive illustration of Indonesian youth language.

\section{Acknowledgement}

We would like to thank students and teachers of SMP and SMK Putra Pertiwi Tangerang Selatan, Mrs. Monica Patti and Mrs. Novianty Elizabeth Ayuna, students and teachers of SMP 2 Kota Tangerang, and SMA 1 Kota Tangerang who participated in this project. We would also like to thank Amalia Shafiyyah Koswara and Muhammad Gani Qodratul Ihsan who collected and handled the data carefully. 


\section{ENDNOTES}

${ }^{i}$ This is a part of the survey on language use and attitude by urban youth in Jakarta, Depok, Tangerang, Bekasi, for the project entitled "Pemerolehan Variasi Bahasa Indonesia pada Anak-anak Keluarga Urban", funded by Directorate General of Higher Education, The Ministry of Higher Education, under the scheme of Penelitian Dasar Unggulan Perguruan Tinggi (PDUPT) (NKB.1503/UN2.R3.1/HKP.05.00/2018).

ii The finding is in line with Parker and Nilan (2013), that parents of middle-class families - especially civil servants and teachers - send their children to SMP and SMU. However, Parker and Nilan's statement on SMK, (the vocational school) that students come from lower socio-economic group was not in line with this study.

iii Independent sample t-test is a descriptive statistical analysis, used to determine whether there is a significant difference between the means of two groups (https://statistics.laerd.com/statistical-guides/independent-t-teststatistical-guide.php). In this case, we observe the means scores of the language choice between the SMP group and SMU group.

\section{REFERENCES}

Ananta, A., et al. ( 2015). Demography of Indonesia's ethnicity. Singapore: ISEAS Publishing.

Bell, A. (1984). Language style as audience design. Language in Society 13 (2): 145-204.

Bell, A. (2001). Back in style: Reworking audience design. In P. Eckert and J.R. Rickford (Eds.). Style and Sociolinguistic Variation. Cambridge: Cambridge University Press, 221-248.

Bucholtz, M. (2001). The whiteness of nerds: Superstandard English and racial markedness. Journal of Linguistic Anthropology 11(1): 84-100.

Bucholtz, M. (2006). Word up: Social meanings of slang in California youth culture. In Jane Goodman \& Leila Monaghan (eds.), Interpersonal communication: An ethnography approach. Malden, MA: Blackwell, 243-267

Djenar, D.N. (2012). Almost unbridled: Indonesian youth language and its critics. South East Asia Research 20 (1): 35-51.

Djenar, D. N. (2014). Adolescent social media interaction and authorial stance in Indonesian teen fiction. Wacana: Journal of the Humanities of Indonesia, 15(1): 166-180.

Djenar, D. N. (2015). Youth Language in Indonesia and Malaysia: From Slang to Literacy Practices. In D.N. Djenar (ed.) Youth Language in Indonesian and Malaysia. NUSA Linguistic Studies in and around Indonesia, 58: 1-8.

Djenar, D. N. and Ewing, M.C. (2015). Language varieties and youthful involvement in Indonesian fiction. Language and Literature 24(2): 108-128.

Djenar, D. N., Ewing, M., and Manns, H. (2018). Style and Intersubjectivity in Youth Interaction. Boston/Berlin: Walter de Gruyter GmbH \& Co KG.

Eckert, P. (2000). Language Variation as Social Practice. Oxford: Blackwell.

Ewing, M.C. (2015). The kalau framing construction in Indonesian comics. In D.N. Djenar (ed.) Youth Language in Indonesian and Malaysia. NUSA 58: 51-71.

Forbes, D. (2004). Jakarta: Globalization, economic crisis, and social change. In J. Gugler (ed.). World Cities beyond the West. Cambridge: Cambridge University Press, 268-296.

Holmes, J. (2013). An introduction to Sociolinguistics (Fourth Edition). New York: Routledge.

Indrayanti, T. (2017). Potret penggunaan bahasa remaja dalam perspektif kalangan mahasiswa. Proceeding of PRASASTI II 'Kajian Pragmatik dalam berbagai Bidang', 126-131. http://dx.doi.org/10.20961/pras.v0i0.88.g72 
Kushartanti, B. (2014). Studi awal mengenai penggunaan bahasa di kalangan remaja di Jakarta dan sekitarnya. [A preliminary study on language use in adolescents in Jakarta and surroundings]. In 75 tahun Prof. Dr. Harimurti Kridalaksana: Persembahan bagi Peneroka Linguistik Indonesia. Depok: Fakultas Ilmu Pengetahuan Budaya Universitas Indonesia, 150-162.

Kushartanti, B. (2016). Nge-: Prefiks baru untuk anak-anak? [Nge-: A new prefix for children?] In Mahaguru yang Bersahaja: Persembahan untuk Prof. Dr. Muhadjir. Depok: Fakultas Ilmu Pengetahuan Budaya Universitas Indonesia, 93-109.

Manns, H. (2015). Address terms, framing and identity in Indonesian youth interaction. In D.N. Djenar (ed.) Youth Language in Indonesian and Malaysia. NUSA 58: 79-83.

Milroy, J., and Milroy, L. (2012). Authority in language: Investigating standard English (Fourth Edition). London: Routledge.

Na'im, A. \& Syaputra, H. (2011). Kewarganegaraan, suku bangsa, agama, dan bahasa sehari-hari penduduk Indonesia: Hasil sensus penduduk 2010. [Citizenship, ethnicity, religion, and everyday language among the residents of Indonesia: Outcomes from the 2010 census]. Jakarta: Badan Pusat Statistik.

Papalia, D. E. \& Martorell, G. (2015). Experience human development. New York: Mc Graw Hill Education.

Parker, L. \& Nilan, P. (2013). Adolescents in contemporary Indonesia. London: Routledge.

Sarwono, S. (2014). Anak Jakarta: A sketch of Indonesian youth identity. Wacana: Journal of Humanities of Indonesia, 15(1): 41-45.

Sitanala, F. (2005). Pergerakan penduduk Kota Depok menuju ke tempat bekerja Tahun 2001. Makara Journal of Science Vol. 9 (1): 41-44.

Subiyatningsih, F. (2007). Karakteristik bahasa remaja: Kasus rubrik remaja "Deteksi" dalam harian Jawa Pos. Journal of Humaniora, 19(2): 185-194. https://doi.org/10.22146/jh.v19i2.903

Subiyatningsih, F. (2016). Sikap bahasa remaja - Kasus pemakaian Bahasa Indonesia dalam Rubrik "Deteksi" Jawa Pos. Madah: Jurnal Bahasa dan Sastra, 7(2): 147-158. https://doi: 10.31503/madah.v7i2.424

Swandy, E. (2017). Bahasa gaul remaja dalam media sosial Facebook. Jurnal Bastra, 1(4): 1-19

Tamtomo, K. (2014). The push and pull of language: Youth written communication across a range of text in Central Java. In D.N. Djenar (ed.) Youth Language in Indonesian and Malaysia. NUSA Linguistic Studies in and around Indonesia, 58: 95-128.

Tamtomo, K. (2016). The push and pull of language ideologies: Multilingual communicative practices among youths in Indonesia city. Thesis. State University of New York at Albany.

Wouk, F. (1999). Dialect contact and koineization in Jakarta, Indonesia. Language Sciences 21: 61-86.

Yannuar, N. \& Kadarisman, A. E. (2015). On the phonetics, phonology, and phonotactics of Basa Walikan Malang. Paper presented in the Fifth International Symposium on the Languages of Java. Universitas Pendidikan Indonesia, Bandung, 6-7 June 2015. 